\title{
In-Vitro Determination of Biological and Anabolic Functions of Weak Androgen Dehydroepiandrosterone (DHEA) Using a Variety of Cell Lines
}

\author{
James L. Cox ${ }^{1}$, Yingzi Chang'2, Pandurangan Ramaraj ${ }^{*}$ \\ ${ }^{1}$ Department of Biochemistry, Kirksville College of Osteopathic Medicine, A.T. Still University of Health Sciences, \\ Kirksville, MO, USA \\ ${ }^{2}$ Department of Pharmacology, Kirksville College of Osteopathic Medicine, A. T. Still University of Health \\ Sciences, Kirksville, MO, USA \\ Email: ${ }^{*}$ Pramaraj@atsu.edu
}

Received 28 June 2015; accepted 23 August 2015; published 26 August 2015

Copyright $(0) 2015$ by authors and Scientific Research Publishing Inc.

This work is licensed under the Creative Commons Attribution International License (CC BY). http://creativecommons.org/licenses/by/4.0/

c) (7) Open Access

\begin{abstract}
Dehydroepiandrosterone (DHEA) is a weak androgen and is shown to have anti-cancer, anti-atherogenic, anti-adipogenic and anti-inflammatory effects on mouse, rat and rabbit models. However, human clinical trials data did not support animal findings and were inconclusive. These systemic differences in biological actions between rodents and humans were attributed to the low level of DHEA in rodents. In order to further understand the differences in biological functions between rodents and humans, we resorted to an in-vitro approach involving mouse, rat and human cell lines to assess DHEA biological and anabolic functions separately and independently without systemic influence. Results indicated that DHEA was effective on mouse and rat cell lines but not on human cell lines, as observed in in-vivo studies. In addition, our in-vitro study showed that DHEA was able to induce myogenesis in mouse mesenchymal cells revealing its anabolic function, even though DHEA was considered as a weak androgen. This observation lent credence to the ban on DHEA by IOC medical commission, citing DHEA as an anabolic steroid. These in-vitro experiments suggested that the differences in biological actions of DHEA between rodents and humans existed not only in-vivo at the systemic level, but also in-vitro at the cellular level and thus paving the way to study the mechanism responsible for these differences at the cellular level itself.
\end{abstract}

\section{Keywords}

Dehydroepiandrosterone, Various Cell Lines, Biological Functions, Anabolic Function

\footnotetext{
${ }^{*}$ Corresponding author.
} 


\section{Introduction}

DHEA is the most abundant androgen (male steroid hormone) secreted by the adrenal cortex [1] and to a lesser extent by testes [2] and ovaries [3]. DHEA is also synthesized in brain and skin [4]. DHEA is metabolized into and rostenedione in the body and may further be converted into either testosterone or estrogen [5] [6]. Eventhough DHEA is a weak androgen, it is present in high concentration both in males and females [7]. So, it raises the question whether it acts through androgen receptor or estrogen receptor or its own receptor [8]. Hence, DHEA's physiological function is still not clear [9]. DHEA circulates in the blood stream mainly as the sulfated form DHEAS [10] [11]. The half-life of DHEAS is 7 - 10 hrs, whereas the half-life of DHEA is only 15 - 30 min [10]. Adult blood levels of DHEAS are 100 - 500 times higher than testosterone and 1000 - 10,000 times higher than Estradiol [11] [12]. DHEAS is converted to DHEA and then to sex hormones in body tissues. Blood levels are highest in developing fetus, dropping sharply after birth, beginning climbing again at age 6 - 8 to a peak level at age 25 - 30 and then declining to about $10 \%$ of the peak level by age 80 [11] [12]. There is no change in DHEAS serum level before the age of 90 and men over 90 with the highest serum DHEAS level show the best functional status [10] [11].

Since circulating level of DHEA peaks at age 25 and then steadily declines with age, some researchers consider DHEA as a possible anti-aging hormone. Considerable interest in DHEA has been developed in recent years with reports that it may play a role in the aging process. DHEA deficiencies in older individuals have been associated with a number of medical conditions ranging from cancer, cardiovascular disease, impaired memory and mental function and osteoporosis [12]-[15]. DHEA levels are also low in persons who are obese and those who have muscle atrophy. Low level is present in male impotence [12]-[15]. Administration of DHEA to rodents suppressed weight gain without significantly affecting food intake, ameliorated the severity of diabetes in genetically diabetic mice and restrained immune processes [9] [16]. DHEA offered protection against spontaneous tumors and chemical carcinogenesis. Also it depressed the mitogenic effects of carcinogenesis, tumor promoters and blocked viral and carcinogen induced cell transformation in mouse [16]. In view of the above beneficial findings in rodents, clinical trials were carried out with DHEA, but without any positive or conclusive data [17]-[21]. The United States Food and Drug Administration removed DHEA supplement from the market in 1985 due to false claims about health benefits [13]. However, since the passing of the US dietary supplement health and education act of 1994 [13], DHEA has made its way back to the market (health food stores, pharmacies and groceries) and its popularity continues to grow.

DHEA’s purported uses include 1) Addison's disease, 2) Alzheimer's disease, 3) Atherosclerosis, 4) Cancer treatment, 5) Depression, 6) Immunostimulation, 7) Memory loss, 8) Rheumatoid arthritis, 9) Schizophrenia, 10) Sexual performance, 11) Systemic Lupus Erythematoses (SLS) and 12) Weight gain and Weight loss [12]-[16]. Since, DHEA is a prohormone that can be converted by the body to other sex hormones such as testosterone and estrogen, it is important to find out whether DHEA has any toxic side effects like testosterone. Since, DHEA may increase the production of the male hormone testosterone, women should be aware of the risk of developing signs of masculinization (such as loss of hair on the head, deepening of the voice, hair growth on face, weight gain around waist or acne). Similarly, men should be aware of the risks of excess testosterone (such as shrinkage of testicles, aggressive tendencies including sexual aggression, male pattern baldness and high blood pressure). There are mixed reports on the receptor through which DHEA acts [8]. Research with genome-wide analysis of DHEA and DHT induced genes expression in mouse hypothalamus and hippocampus demonstrated that DHEA was intrinsically androgenic [22]. It competed with DHT for binding to androgen receptor and induced androgen receptor (AR) regulated reporter gene expression in-vitro [22].

Since, there was no supporting clinical trial in humans to back-up the beneficial findings in small animals (mouse, rat and rabbit) and the fact that people consumed DHEA as a dietary supplement without knowing that DHEA was a weak androgen, our objective was to determine DHEA's biological and anabolic functions in-vitro using mouse, rat and human cell-lines.

\section{Materials and Methods}

\subsection{Chemicals}

DHEA (dehydroepiandrosterone), MTT (3-[4,5-Dimethylthiazol-2-yl]-2,5-diphenyl tetrazolium bromide), iso- 
propanol, paraformaldehyde, Oil red O stain were purchased from Sigma chemical company, St. Louis, MO. Fetal bovine serum (FBS), Trypsin-EDTA $(1 \times)$ and PBS powder were purchased from Atlanta biologicals, Lawrenceville, GA. RPMI and antibiotic/antimycotic solution 100× (10,000 I.U/ml penicillin, $10 \mathrm{mg} / \mathrm{ml}$ streptomycin, $25 \mu \mathrm{g} / \mathrm{ml}$ amphotericin-B) were purchased from Fisher scientific, Houston, TX.

\subsection{Growth Medium (GM)}

All cancer cell culture works were carried out in RPMI 1640 medium containing 10\% FBS +1× Pen/Strep/Ampho as described in references [23] [24].

\subsubsection{Cell Growth Assay}

MTT proliferation assay [25] was used to quantitate cell growth in treated (with DHEA) and in untreated (control) samples. In addition, microscopic pictures of cells treated with hormone were taken to document hormonal effects on cell lines.

\subsubsection{MTT Proliferation Assay [25]}

B16F10 cells, BLM cells and NUGC3 cells were suspended in growth medium (GM) and plated at a density of $1 \times 10^{4}$ cells/well in a 96 well plate. Cells were left overnight at $37^{\circ} \mathrm{C}$ to attach to the plate. Following day growth medium was replaced by GM containing DHEA hormone at different concentrations and incubated for 48 hrs. After 48 hrs, medium was replaced by $100 \mu$ of 1 in 10 diluted (in GM) MTT solution and incubated for another $4 \mathrm{hrs}$ at $37^{\circ} \mathrm{C}$. After $4 \mathrm{hrs}$ MTT solution was removed. MTT was reduced by metabolically viable cells to a colored (purple) water insoluble formazan salt. The purple color precipitate was solubilized by adding 100 $\mu \mathrm{l}$ of isopropanol and shaken for 20 - $30 \mathrm{~min}$ at room temperature. Intensity of resultant purple color was measured at $570 \mathrm{~nm}$ in a SLT spectra plate reader.

\subsection{Rat Vascular Smooth Muscle Cell Culture}

Procedure for isolation of rat aortic vascular smooth muscle cells was described in reference [26]. A petri dish containing cells at 6/7 passage was obtained from a colleague. Cells were harvested from the plate using trypsin-EDTA and were re-plated in a 96 well plate in DMEM/F12 medium. Cells were left for 2 - 3 days to become $70 \%$ to $80 \%$ confluent. Regular medium was replaced by medium containing 10 and $100 \mu \mathrm{M}$ concentrations of DHEA and incubated for 48 hrs. At the end of 48 hrs, MTT assay was carried out to quantitate cell growth.

\subsection{Mouse 3T3-L1 Preadipocyte Culture}

Mouse 3T3-L1 preadipocyte (American Type culture collection, Manassas, VA) was maintained in growth medium (GM) containing DMEM supplemented with 10\% FBS as described previously [27]. Differentiation was induced in 100\% confluent 3T3-L1 cells by incubating in adipogenic medium (AM) (GM with 0.5 mM isobutylmethylxanthine, $1 \mu \mathrm{M}$ dexamethasone and $10 \mu \mathrm{g} / \mathrm{ml}$ insulin) for three days with or without androgens. This was followed by changing the medium to GM containing $10 \mu \mathrm{g} / \mathrm{ml}$ insulin with or without androgens at various concentrations for another 2 days and then to GM plus treatments for up to 10 days.

\subsection{Oil Red 0 Staining}

Cells were fixed in 2\% paraformaldehyde after treatments and stained with $0.3 \%$ Oil Red $\mathrm{O}$ for 15 min as described [28]. For quantitative analysis of Oil red O retention in these cells, stained adipocytes were extracted with $1 \mathrm{ml}$ of 4\% Igepal CA-630 (Sigma) in isopropanol and absorbance was measured by spectrophotometer at $520 \mathrm{~nm}$.

\subsection{Mouse Mesenchymal Multipotent Cell Culture}

Mouse $10 \mathrm{~T} 1 / 2$ cells grown at $37^{\circ} \mathrm{C}$ in DMEM with $10 \%$ FBS, $4 \mathrm{mM}$ glutamine, and $1 \times$ antibiotic-antimycotic (GM), were treated with $20 \mu \mathrm{M}$ 5-azacytidine (aza) in GM. After 3 days cells were split 1:2 and were allowed to recover in GM for 2 days. Cells were seeded at 70\% confluence in 6-well plates or chamber-slides and were grown with DHEA for 0 to14 days [27]. 


\subsection{Immunohistochemistry}

For immunochemical analyses, cells grown in chamber slides were fixed in $2 \%$ paraformaldehyde for 20 min, quenched with $\mathrm{H}_{2} \mathrm{O}_{2}$, blocked with normal horse serum and incubated with anti-myosin heavy chain II (MHCII) antibody [27]. Detection was based on a secondary biotinylated antibody, followed by the addition of streptavidin-horseradish peroxidase ABC complex (1:100) (Vectastain Elite ABC System, Novocastra Laboratories, Newcastle upon Tyne, UK) and 3,3-diaminobenzidine. The cells were counter-stained with Meyer's hematoxyline.

\subsection{Reverse Transcription-PCR}

Total RNA was extracted from cells by using Trizol reagent (Invitrogen, Carlsbad, CA) and was purified and characterized by measuring at $A_{260}$. Two micrograms aliquot of total RNA was reverse transcribed and the resulting cDNA was amplified for 35 PCR cycles by melting at $94^{\circ} \mathrm{C}$ for $30 \mathrm{sec}$, primer annealing at $58^{\circ} \mathrm{C}$ for 30 sec and extension at $72^{\circ} \mathrm{C}$ for $1 \mathrm{~min}$. PCR products were analyzed by electrophoresis in $1.5 \%$ agarose gel using ethidium bromide staining [27]. The locations of DNA sequences for the forward/reverse PCR primers are as follows: C/EBP $\alpha$ (225 bp), 843 - 864/1067 - 1047 on NM_007678; and GAPDH (152 bp) 606 - 626/758 - 738 on BC023196.

\subsection{Statistical Analysis}

Data are presented as mean \pm SEM. The experiments were repeated a minimum of three times for consistency and representative cell pictures from experiments were shown. Pair-wise comparison between groups was performed using Student's t-test. P value less than 0.05 was considered as statistically significant.

\section{Results}

\subsection{DHEA Biological Actions}

\subsubsection{Effect of DHEA on Mouse Melanoma (B16F10) Cell Growth}

Addition of DHEA to mouse melanoma cells showed a significant decrease in cell growth between $10 \mu \mathrm{M}$ and $100 \mu \mathrm{M}$ concentrations. DHEA decreased mouse melanoma cell growth to $93.4 \%$ at $10 \mu \mathrm{M}$ and $46.2 \%$ at 100 $\mu \mathrm{M}$ concentrations. Actually, cell morphology was slightly different between control (untreated) and treated cells as shown in Figure 1. The change in cell morphology was due to differentiation of cells as reported earlier [29].

\subsubsection{Effect of DHEA on Human Melanoma (BLM) Cell Growth}

Though addition of DHEA to human melanoma cells showed difference in cell growth between untreated control and treated cells, there was no significant dose-dependent decrease in cell growth between DHEA $10 \mu \mathrm{M}$ and $100 \mu \mathrm{M}$ concentrations. Ten $\mu \mathrm{M}$ DHEA treated cell growth was $86 \%$, whereas $100 \mu \mathrm{M}$ DHEA treated cell growth was $82.7 \%$ as shown in Figure 2. DHEA affected only marginally human melanoma cell growth. The reason for this muffled response of human melanoma cells to DHEA treatment was not known. However, this observation supported clinical trial data [17].

\subsubsection{Effect of DHEA on Human Gastric Cancer (NUGC3) Cell Growth}

Since DHEA was essential for healthy skin and was also synthesized in the skin, effects of DHEA on mouse and human melanoma cancer cell lines (target cancer) were checked. Later, we extended our investigation to nontarget cancer cells to check whether DHEA had any effect on other cancer. As human gastric cancer (NUGC3) cell was earlier used to study the effect of Orlistat on cell growth and was found to inhibit gastric cancer cell growth [30], we used gastric cancer cell line to study the effect of DHEA on cell growth. There was no effect of DHEA on gastric cancer cell growth. There was no difference between untreated and treated cells even at 100 $\mu \mathrm{M}$ concentration of DHEA as shown in Figure 3. The two experiment results, first one with human melanoma cell line and second one with human gastric cancer cell line supported the clinical trial outcome for DHEA.

\subsubsection{Effect of DHEA on Normal Rat Vascular Smooth Muscle Cells}

In order to understand the role of DHEA as an anti-atherogenic agent, we used normal rat vascular smooth muscle 


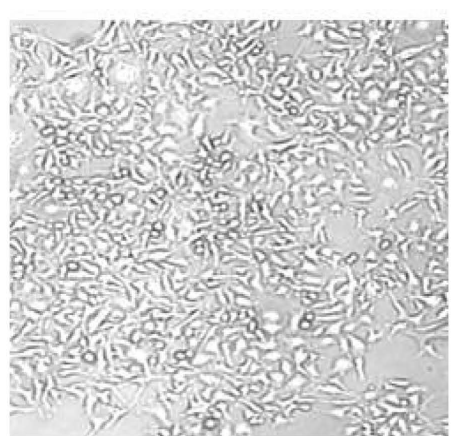

Neat control

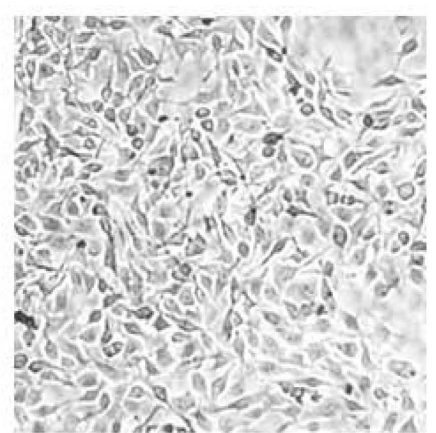

DH-10 $\mu \mathrm{M}$

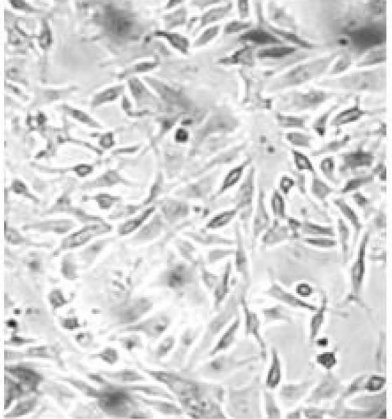

DH-100 $\mu \mathrm{M}$

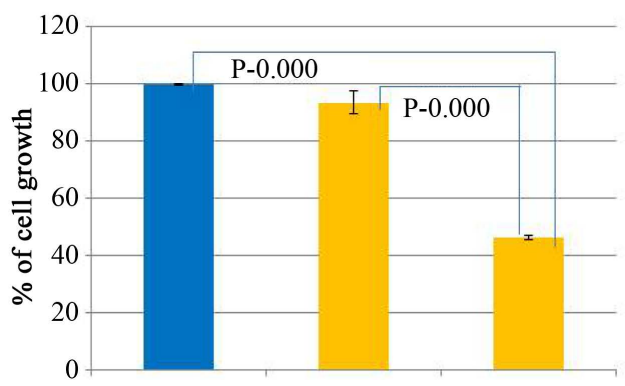

Figure 1. Treatment of mouse melanoma (B16F10) cells with DHEA: DHEA treatment showed a significant decrease in cell growth between untreated control and DHEA-100 $\mu \mathrm{M}$ treated cells (P value of 0.000$)$ and also differentiation of mouse melanoma cells (10× magnification). Similarly a significant decrease in cell growth was noticed between DHEA-10 $\mu$ M and DHEA-100 $\mu \mathrm{M}$ treatment as shown by a P-value of 0.000 .

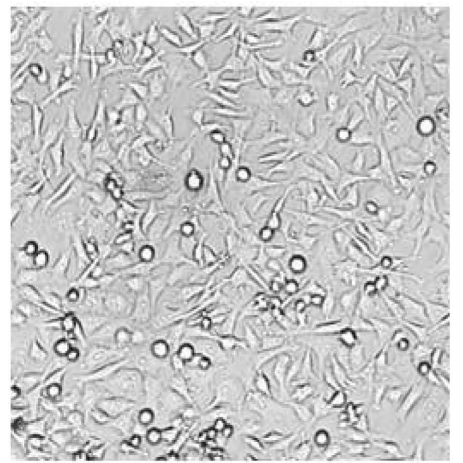

Neat control

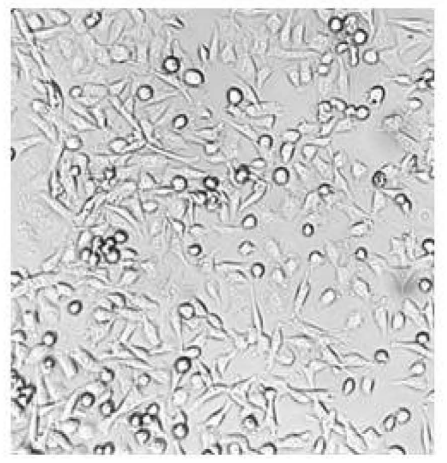

DH-10 $\mu \mathrm{M}$

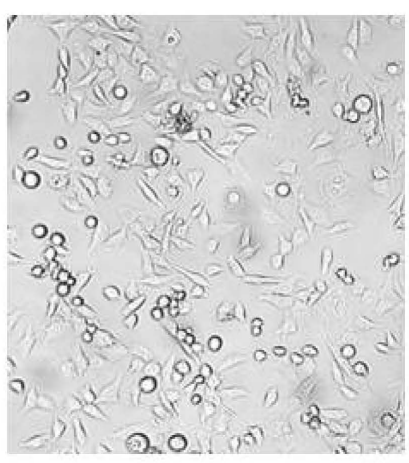

DH-100 $\mu \mathrm{M}$

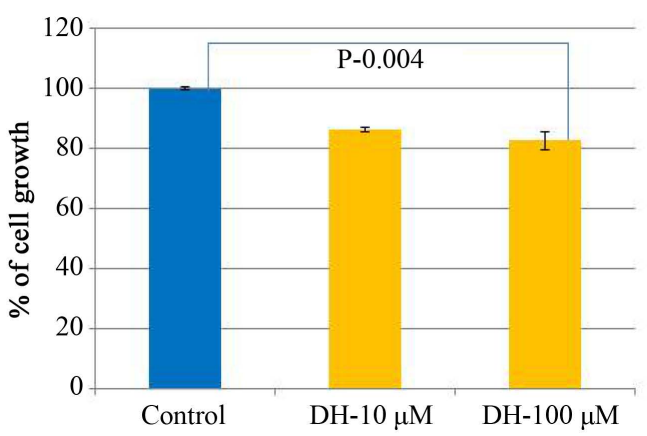

Figure 2. Treatment of human melanoma (BLM) cells with DHEA: There was no significant inhibition of human melanoma cell growth at 10 and $100 \mu \mathrm{M}$ concentrations of DHEA (P-value 0.299 ) as shown in the picture. Though comparison of cell growth between untreated control and DHEA $100 \mu \mathrm{M}$ treated cells showed a marginal effect on cell growth, yet it was statistically significant with a P-value of 0.04 by MTT assay. 
cells to study the effect of DHEA on cell growth and morphology. Vascular smooth muscle cells were isolated from normal rat carotid artery and incubated with DHEA at 10 and $100 \mu \mathrm{M}$ concentrations. After $48 \mathrm{hrs}$ of incubation, DHEA decreased rat vascular smooth muscle cell growth slightly (86.6\% at $100 \mu \mathrm{M}$ conc.) as shown in Figure 4. Visually there were fewer cells in $100 \mu \mathrm{M}$ DHEA treated group, but cells were larger in size. The larger size could be due to association of cells or differentiation of cells as reported earlier [31] [32]. Yet, there was no significant dose-dependent decrease in cell growth in DHEA treated cells, as shown by the quantitative MTT assay (Figure 4).

\subsubsection{Effect of DHEA on 3T3-L1 Preadipocyte Cells}

DHEA was anti-adipogenic and decreased fat synthesis [33] [34]. So, 3T3-L1 preadipocyte cells were treated with DHT $10 \mathrm{nM}$ (as positive control) and DHEA as test hormone at $10 \mathrm{nM}, 100 \mathrm{nM}, 1 \mu \mathrm{M}$ and $10 \mu \mathrm{M}$ concentrations. After 10 - 12 days cells were stained with Oil red O stain and extracted with isopropanol for quantitation. Quantitation of adipogenesis showed a gradual decrease in adipogenesis from $10 \mathrm{nM}$ to $10 \mu \mathrm{M}$ as shown in Figure 5. DHEA decreased adipogenesis in 3T3-L1 preadipocytes to 79\% at $10 \mu \mathrm{M}$ conc. Decreases in adipogenesis were seen at $1 \mu \mathrm{M}$ and $10 \mu \mathrm{M}$ concentrations of DHEA compared to untreated control cells.

\subsection{DHEA Anabolic Action}

Effect of DHEA on myogenesis: Eventhough DHEA was shown to have anti-cancer, anti-adipogenic and anti-atherogenic actions on mouse and rat models, the underlying fact was DHEA was a weak androgen and an intermediate in testosterone biosynthesis. Also DHEA was an immediate precursor of androstenedione, another weak androgen, which was shown to promote myogenesis [35]. AD was recently banned as over the counter supplement because of its toxic side effects. So, the anabolic action of DHEA was checked by using in-vitro

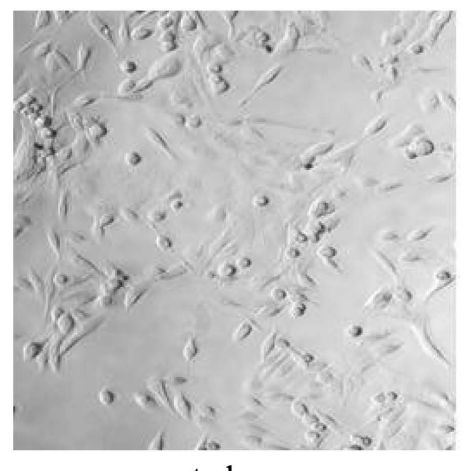

control

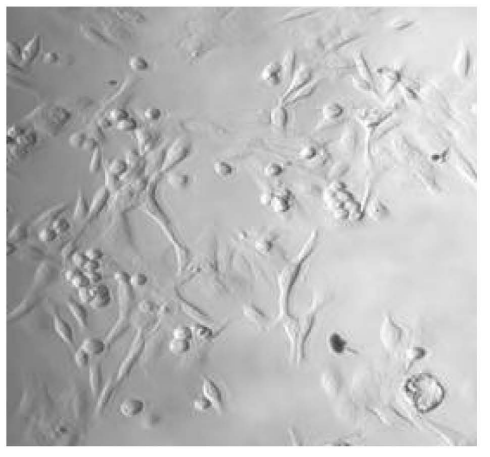

$\mathrm{DH}-10 \mu \mathrm{M}$

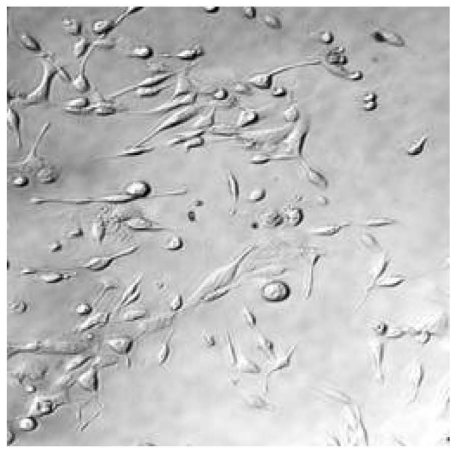

DH-100 $\mu \mathrm{M}$

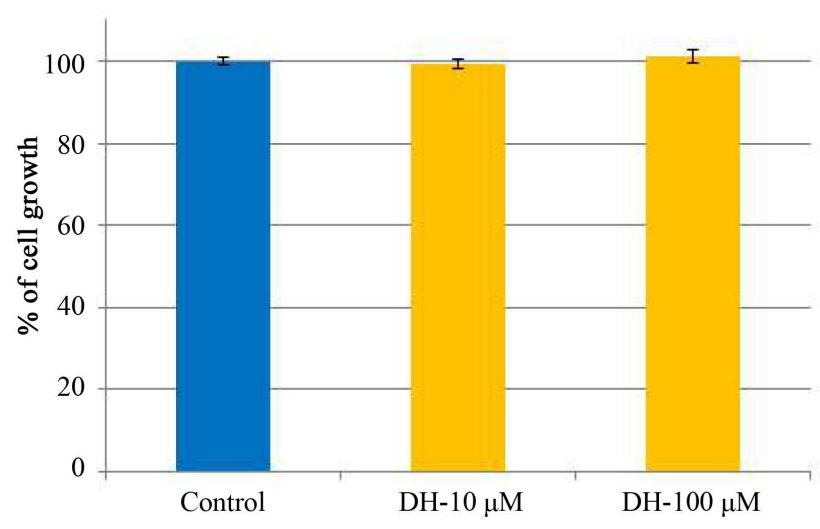

Figure 3. Treatment of human gastric cancer (NUGC3) cells with DHEA: In order to check the effect of DHEA on other cancer, we used human gastric cancer (NUGC3) cell line. DHEA did not show any effect on the growth of human gastric cancer cells even at $100 \mu \mathrm{M}$ concentration. There was no difference in cell growth between control (untreated) and DHEA $(10$ and $100 \mu \mathrm{M})$ treated cells, as shown by the MTT assay. 


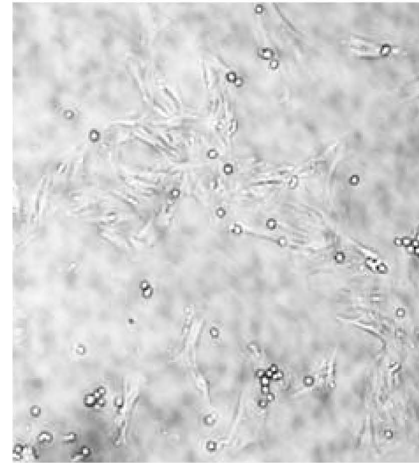

control

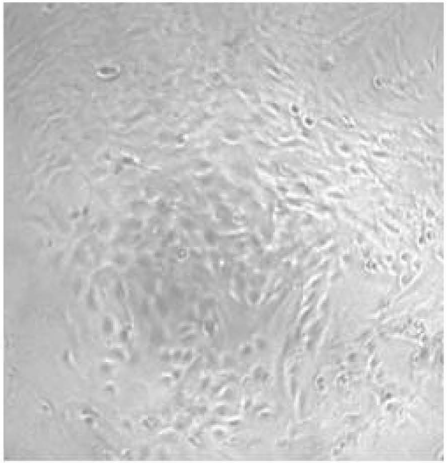

$\mathrm{DH}-10 \mu \mathrm{M}$

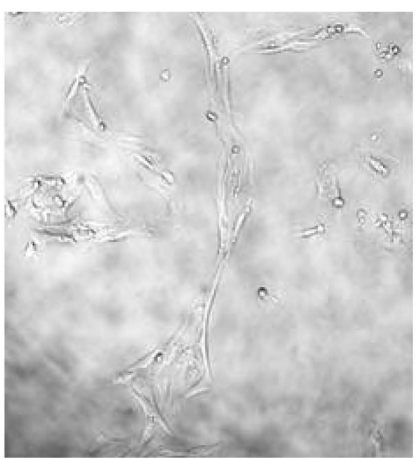

DH-100 $\mu \mathrm{M}$

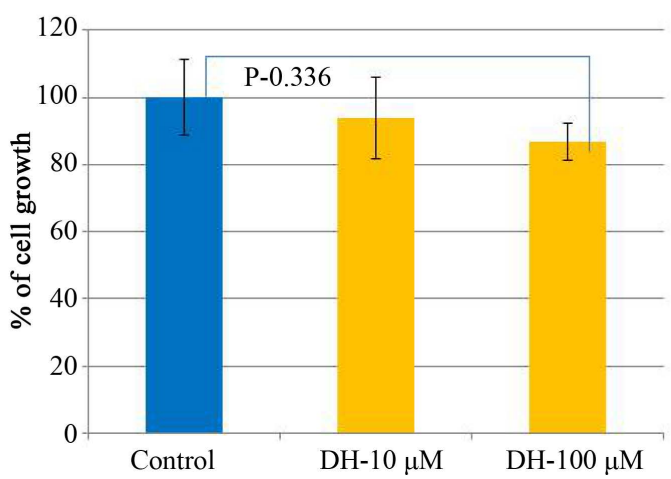

Figure 4. Treatment of rat vascular smooth muscle (VSMC) cells with DHEA: DHEA was shown to be anti-atherogenic by virtue of its action on vascular smooth muscle cells. So, we used normal rat sub-cultured vascular smooth muscle cells to check the effect of DHEA on smooth muscle cell growth. As reported, DHEA induced differentiation of smooth muscle cells and thereby caused a decrease in cell growth compared to the control cells. However, the difference in cell growth between control and DHEA-100 $\mu \mathrm{M}$ was not significant as shown by the P-value (0.336). Similarly, the difference in cell growth between DHEA-10 $\mu \mathrm{M}$ and DHEA-100 $\mu \mathrm{M}$ was not significant as given by the P-value of 0.621 by MTT assay.

Control cells

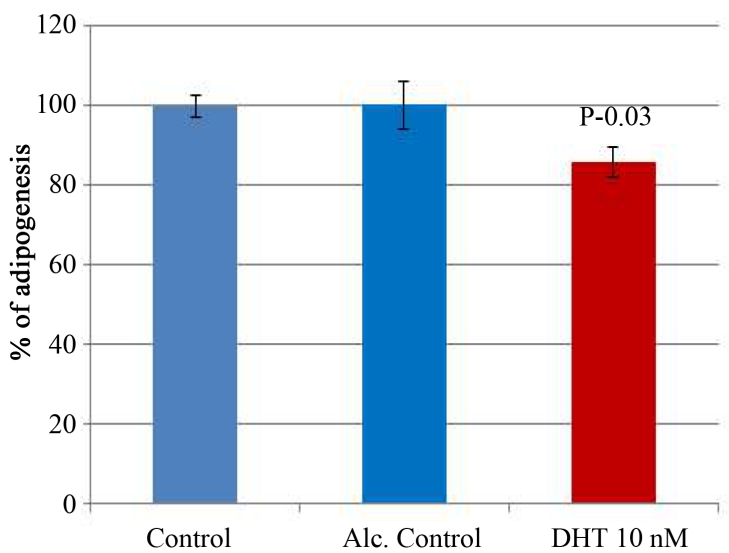

DHEA treated cells

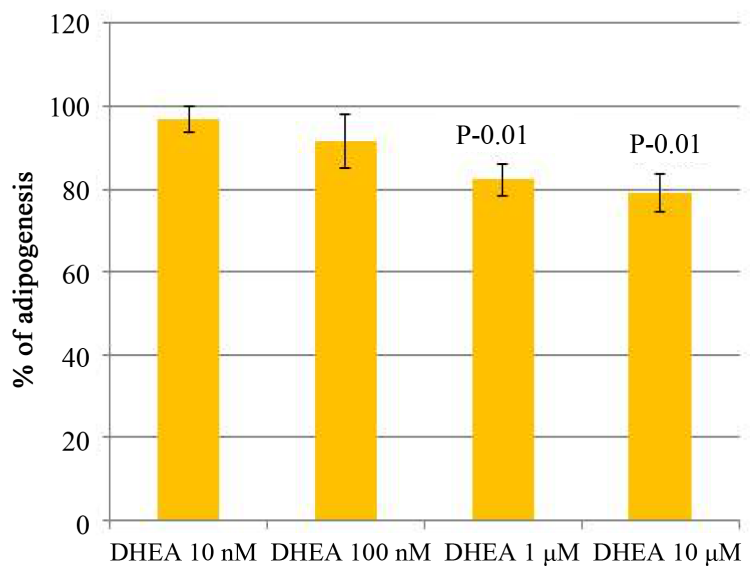

Figure 5. Colorimetric quantitation of adipogenesis in control and DHEA treated pre-adipocyte (3T3-L1) cells: DHEA effect on adipogenesis was checked using 3T3-L1 preadipcytes. Control panel cells showed no difference in growth between untreated and alcohol treated cells. However, with powerful androgen DHT (10 nM), adipogenesis was decreased when compared to control cell as shown by a P-value of 0.03. Though DHEA showed a dose-dependent decrease in adipogeneis, the decrease was not significant at DHEA-10 nM and DHEA-100 nM concentrations when compared to the control, as determined by the P-value ( 0.49 and 0.30 respectively). But, DHEA1 $\mu \mathrm{M}$ and DHEA-10 $\mu \mathrm{M}$ concentrations showed a significant decrease in adipogenesis when compared to the control as shown by the P-value of 0.01 and 0.01 respectively. 
mesenchymal differentiation assay. This assay was used to demonstrate the anabolic action of powerful androgens $\mathrm{T}$ and DHT [35]. Since, DHEA was used in conjunction with $\mathrm{T}$ and DHT, where T concentrations were 30 and $100 \mathrm{nM}$ and DHT concentration was $10 \mathrm{nM}$, we kept the maximum concentration of DHEA to $10 \mu \mathrm{M}$ and did not try $100 \mu \mathrm{M}$ concentration of DHEA in the anabolic and the adipogenic experiments. Mouse mesenchymal (10T1/2) cells were treated with DHEA $100 \mathrm{nM}$ (low) and $10 \mu \mathrm{M}$ (high) concentrations. After 10 - 12 days of treatment, cells were checked for myotube formation by carrying out immunohistochemical staining for myosin heavy chain IIb (MHCIIb) protein, terminal myogenic marker. As shown byimmunohistochmical staining for MHCIIb protein (Figure 6(a)), there were myogenesis in $100 \mathrm{nM}$ and $10 \mu \mathrm{M}$ DHEA treated cells. So DHEA stimulated myogenesis at low and high concentrations, just like the other weak androgen AD [35]. Biochemically myogenesis was confirmed by RT-PCR for MHCIIb RNA expression (Figure 6(b)). Reverse transcription PCR for androgen receptor (AR), showed the expression of AR (Figure 6(b)) following treatment with DHEA. AR expression in 10T1/2 cells was also shown in previous studies [35]-[37] following treatments with $A D, D H T$ and T.
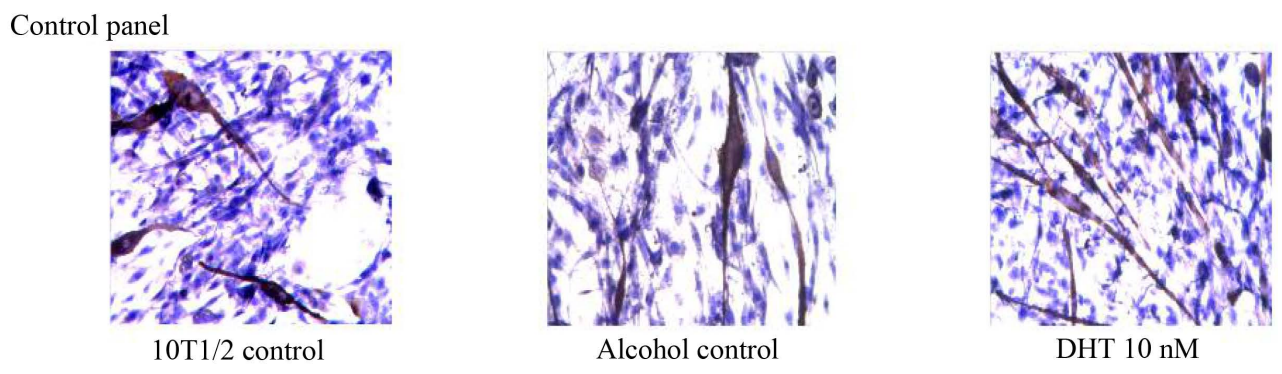

Experimental panel

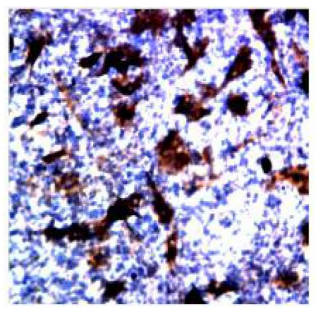

DHEA-100 nM

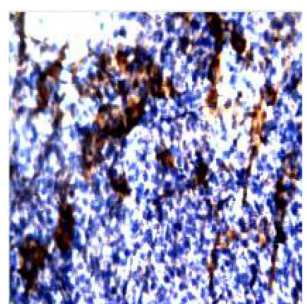

DHEA-10 $\mu \mathrm{M}$

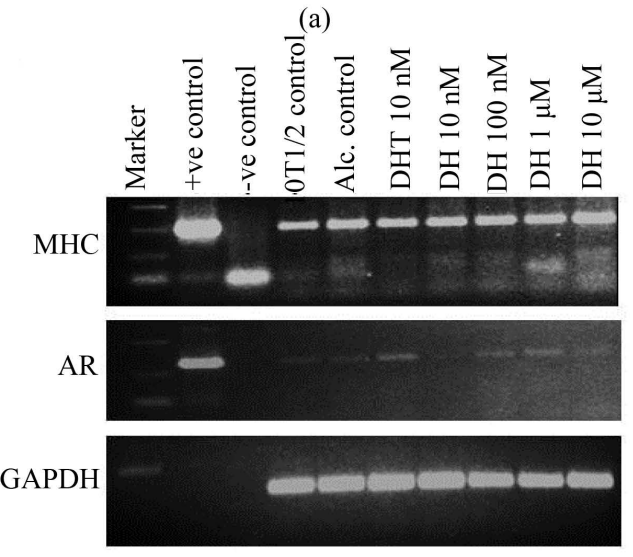

(b)

Figure 6. (a) Immunohistochemical staining for MHC-II protein after treatment of mouse mesenchymal (10T1/2) cells with DHEA: The anabolic effect of DHEA was checked using mouse mesenchymal multipotent (10T1/2) cells. The control panel showed an increase in myogenesis with powerful androgen DHT $(10 \mathrm{nM})$. DHEA also stimulatedmyogenesis at low $(100 \mathrm{nM})$ and at high $(10 \mu \mathrm{M})$ concentrations, as indicated by the brown immunohistochemical staining. (b) RT-PCR for myogenic marker expression: Expression of biochemical marker for myogenesis, MHC-IIbRNA was shown by RT-PCR. In addition AR was also shown to be expressed on DHEA treated cells. GAPDH was used as control gene expression. 


\section{Discussion}

Based on the beneficial effects of DHEA on small animals, people started taking DHEA as a nutritional supplement. But mouse was not a good model system to study the effect of DHEA, because in mouse very little DHEA was produced compared to human. DHEA was also a weak androgen and hence suspected to have anabolic action naturally associated with androgens. So our aim was to find out the in-vitro effect of DHEA on mouse, rat and human cell lines on its purported benefits and also to assess the anabolic effect of DHEA on myogenesis using an in-vitro mouse mesenchymal differentiation assay.

As DHEA was shown to be present in normal skin, its role in skin cancer (melanoma) was checked. DHEA anti-cancer action was checked on mouse and human melanoma cell lines. As expected DHEA showed a significant effect on mouse melanoma cell line at $100 \mu \mathrm{M}$ concentration, but DHEA did not show any significant effect on human melanoma cell growth even at $100 \mu \mathrm{M}$ concentration. This muffled effect of DHEA on target cancer cell line, prompted us to check the effect of DHEA on non-target gastric cancer cell line and also to check the prowess of DHEA in affecting cancer in general. DHEA did not show any effect on human gastric cancer cell line even at $100 \mu \mathrm{M}$ concentration of DHEA. So far DHEA showed either muffled or no effect on human cancer cell lines.

DHEA was shown to have anti-atherogenic action by virtue of its effect on vascular smooth muscle cells and endothelial cells. So, we decided to study the effect of DHEA on normal rat vascular smooth muscle cells. As reported earlier [31] [32], DHEA was anti-proliferative and induced differentiation of smooth muscle cells. This was confirmed by the appearance of larger and branched cells at $100 \mu \mathrm{M}$ concentration of DHEA. But, again it was another rodent (rat) cell, so DHEA effect was seen.

DHEA was shown to be anti-adipogenic based on its effect on 3T3-L1 preadipocytes, where DHEA showed a dose-dependent decrease in adipogenesis. DHEA anti-adipogenic effect was again seen on a mouse cell line.

So far the in-vitro experiments results supported human clinical trials data by showing a muffled or no effect on human cell lines (Table 1). As DHEA is a precursor of androstenedione, which was shown to have effect on muscle growth by using in-vitro mouse mesenchymal differentiation assay [35], it was important to check the anabolic action of DHEA also. Using this assay, we showed myogenesis upon addition of DHEA to 10T1/2 cells. Moreover, myogenesis was confirmed by the expression of terminal myogenic marker MHCIIb at the RNA and protein levels. Based on previous 10T1/2 studies [35]-[37], where expression of AR in 10T1/2 cells was correlated with the actions

Table 1. Summarizes anti-cancer, anti-atherogenic, anti-adipogenic and anabolic actions of DHEA on a variety of cell lines.

\begin{tabular}{|c|c|c|c|}
\hline \multirow{2}{*}{ DHEA Experiments } & \multicolumn{3}{|c|}{ Cell Lines } \\
\hline & Mouse cell lines & Rat sub-cultured cells & Human cell lines \\
\hline Effect on melanoma cell growth & $\begin{array}{l}\text { Decreased mouse melanoma } \\
\text { cell growth significantly }\end{array}$ & & $\begin{array}{l}\text { No significant decrease on } \\
\text { human melanoma cell growth }\end{array}$ \\
\hline $\begin{array}{l}\text { Effect on gastric } \\
\text { cancer cell growth }\end{array}$ & & & $\begin{array}{l}\text { No effect at all on human } \\
\text { gastric cancer cell growth }\end{array}$ \\
\hline $\begin{array}{l}\text { Effect on vascular smooth } \\
\text { muscle cell growth }\end{array}$ & & $\begin{array}{l}\text { Modeerate decrease in } \\
\text { cell growth due to } \\
\text { differentiation of cells }\end{array}$ & \\
\hline Effect on adipogenesis & $\begin{array}{l}\text { Decreased 3T3-L1 } \\
\text { preadiposcyte differentiation } \\
\text { to fat cell and hence } \\
\text { decreased adipogenesis }\end{array}$ & & \\
\hline Anabolic action & $\begin{array}{c}\text { Promoted differentiation of } \\
\text { mouse mesenchymal stem cell } \\
\text { line } 10 \mathrm{~T} 1 / 2 \text { to myotubes }\end{array}$ & & \\
\hline
\end{tabular}

of androgens (AD, DHT, T) mediated through AR, expression of AR after treatment with DHEA could be mediated through AR. Since, DHEA stimulation of myogenesis through AR and its structural similarity to testosterone, DHEA was anabolic in nature. Moreover, report of an earlier experiment with DHEA showed androgen-specific gene expression in the hypothalamus [22], indicating it was an androgen and also had anabolic action. Recently IOC, medical commission included DHEA in the list of banned chemicals and prevented athletes from using DHEA as a supplement [38] [39]. 
So to summarize, DHEA decreased mouse melanoma cell growth, whereas DHEA affected only marginally human melanoma cell growth. In addition, DHEA did not affect human gastric cancer cell growth even at 100 $\mu \mathrm{M}$ concentration. DHEA induced differentiation in rat vascular smooth muscle cell and decreased fat cell differentiation in 3T3-L1 pre-adiopcytes. DHEA also induced differentiation of mouse mesenchymal multipotent (C3H10T1/2) cells to myotubes. In our in-vitro studies DHEA was effective on rodents (mouse, rat) cell lines. However, DHEA was either marginally effective or not effective on human cell lines (Table 1). The reason for this difference could be due to the difference in the processing or metabolizing of DHEA inside the cells, because our unpublished data showed that atleast in mouse and human melanoma cell lines, DHEA actions were mediated through AR. Eventhough DHEA was a weak androgen, it still exhibited anabolic action as shown by the differentiation of mouse mesenchymal multipotent cells to myotubes. Further recent banning of DHEA use by athletes by the International Olympic Committee's (IOC) medical commission, citing DHEA as an anabolic steroid [38] [39], added credence to the above findings. Our in-vitro results supported the clinical trial data [17], which did not show any beneficial effect on humans. Thus we were able to show the differential biological effects of DHEA between rodents (mouse, rat) and humans at the cellular level itself.

\section{Conclusion}

In conclusion, in-vitro experiments not only supported human clinical trial data, but also showed that the differences in biological actions of DHEA between rodents and humans existed even at the cellular level. The ban on DHEA by IOC medical commission lent credence to the anabolic nature of DHEA, as demonstrated by the myogenic experiment. These in-vitro experiments using cells, thus paved the way for future study to check the mechanism of differences in biological actions of DHEA between rodents and humans at the cellular level itself. This in-vitro approach was emphasized in a recently published biotechniques newsletter [40], where the author Kristie Nybo wrote that dishes of cultured cells could provide new insights into the mechanisms of human diseases (citing advances in in-vitro approach to find a cure for Lou Gehrig disease).

\section{Acknowledgements}

Mouse metastatic melanoma cell line B16F10, human melanoma cell line BLM and human gastric cancer cell line NUGC3 were obtained from a colleague (Dr. James L. Cox) in the department. Sub-cultured normal rat vascular smooth muscle cells (VSMC) and the medium (DMEM/F12) to culture them were obtained from another colleague (Dr. Yingzi Chang) in the Pharmacology department of KCOM. Mouse mesenchymal stem cell line (10T1/2) and 3T3-L1 pre-adipocytes were obtained from Dr. Wayne Taylor, from Charles Drew University, Los Angeles, CA. This research work was supported by the Seed Money grant for Research to Pandurangan Ramaraj from KCOM, A.T. Still University, Grant \#200-889. Help with manuscript preparation and bibliographic works by Sujatha Bhuvanaraj is gratefully acknowledged.

\section{References}

[1] Symington, T., Duguid, W.P. and Davidson, J.N. (1956) Effect of Exogenous Corticotropin on the Histochemical Pattern of the Human Adrenal Cortex and a Comparison with the Changes during Stress. The Journal of Clinical Endocrinology and Metabolism, 16, 580-598. http://dx.doi.org/10.1210/jcem-16-5-580

[2] Hall, P.F., Sozer, C.C. and Eik-Nes, K.B. (1964) Formation of Dehydroepiandrosterone during in Vivo and in Vitro Biosynthesis of Testosterone by Testicular Tissue. Endocrinology, 74, 35-43. http://dx.doi.org/10.1210/endo-74-1-35

[3] Aakvaag, A., Hagen, A.A. and Eik-Nes, K.B. (1964) Biosynthesis in Vivo of Testosterone and Androstenedione from Dehydroepiandrosterone-Sodium Sulfate by the Canine Testis and Ovary. Biochimica et Biophysica Acta, 86, 622-627. http://dx.doi.org/10.1016/0304-4165(64)90102-3

[4] Klatz, R. and Kahn, C. (1997) Grow Young with HGH. Harper Collins Publishers Inc., New York, 186-189, 191.

[5] Labrie, F. (1991) Intracrinology. Molecular and Cellular Endocrinology, 78, C113-C118. http://dx.doi.org/10.1016/0303-7207(91)90116-A

[6] Labrie, F., Belanger, A., Simard, J., Luu-The, V. and Labrie, C. (1995) DHEA and Peripheral Androgen and Estrogen Formation: Intracrinology. Annals of the New York Academy of Sciences, 774, 16-28. http://dx.doi.org/10.1111/j.1749-6632.1995.tb17369.x

[7] Kalimi, M. and Regelson, M. (1990) The Biological Role of Dehydroepiandrosterone (DHEA). Walter de Gruyter, New York. 
[8] Webb, S.J., Geoghegan, T.E., Prough, R.A. and Michael Miller, K.K. (2006) The Biological Actions of Dehydroepiandrosterone Involves Multiple Receptors. Drug Metabolism Reviews, 38, 89-116. http://dx.doi.org/10.1080/03602530600569877

[9] Khorram, O. (1996) DHEA: A Hormone with Multiple Effects. Current Opinion in Obstetrics and Gynecology, 8, 351354. http://dx.doi.org/10.1097/00001703-199610000-00006

[10] Ravaglia, G., Forti, P., Maioli, F., Boschi, F., Bernardi, M., Pratelli, L., Pizzoferrato, A. and Gasbarrini, G. (1996) The Relationship of Dehydroepiandrosterone Sulfate (DHEAS) to Endocrine-Metabolic Parameters and Functional Status in the Oldest-Old. Results from an Italian Study on Healthy Free-Living Over-Ninety-Year-Olds. The Journal of Clinical Endocrinology and Metabolism, 81, 1173-1178.

[11] Labrie, F., Luu-The, V., Belanger, A., Lin, S.-X., Simard, J., Pelletier, G. and Labrie, C. (2005) Is Dehydroepiandrosterone a Hormone? Journal of Endocrinology, 187, 169-196. http://dx.doi.org/10.1677/joe.1.06264

[12] http://www.benbest.com/nutrceut/DHEA.html

[13] Williams, J.R. (2000) The Effects of Dehydroepiandrosterone on Carcinogenesis, Obesity, the Immune System and Aging. Lipids, 35, 325-331. http://dx.doi.org/10.1007/s11745-000-0529-7

[14] http://www.invive.com/dhea.html

[15] http://primev.com/DHEA.htm

[16] Gordon, G.B., Shantz, L.M. and Talalay, P. (1987) Modulation of Growth, Differentiation and Carcinogenesis by Dehydroepiandrosterone. Advances in Enzyme Regulation, 26, 355-382. http://dx.doi.org/10.1016/0065-2571(87)90023-9

[17] Nair, K.S., Rizza, R.A., O’Brien, P., Dhatariya, K., Short, K.R., Nehra, A., Vittone, J.L., Klee, G.G., Basu, A., Basu, R., Cobelli, C., Toffolo, G., Dalla Man, C., Tindall, D.J., Melton III, L.J., Smith, G.E., Khosla, S. and Jensen, M.D. (2006) DHEA in Elderly Women and DHEA or Testosterone in Elderly men. New England Journal of Medicine, 355, 1647-1659. http://dx.doi.org/10.1056/NEJMoa054629

[18] Davis, S.R., Panjari, M. and Stanczyk, F.Z. (2011) DHEA Replacement for Post-Menopausal Women. The Journal of Clinical Endocrinology \& Metabolism, 96, 1642-1653. http://dx.doi.org/10.1210/jc.2010-2888

[19] Villareal, D.T. and Holloszy, J.O. (2004) Effect of DHEA on Abdominal Fat and Insulin Action in Elderly Women and Men. Journal of the American Medical Association, 292, 2243-2248. http://dx.doi.org/10.1001/jama.292.18.2243

[20] Mazat, L., Laofont, S., Berr, C., Debuire, B., Tessier, J.F., Dartigues, J.F. and Baulieu, E.E. (2001) Prospective Measurements of Dehydroepiandrosterone Sulfate in a Cohort of Elderly Subjects: Relationship to Gender, Subjective Health, Smoking Habits, and 10-Year Mortality. Proceedings of the National Academy of Sciences of the United States of America, 98, 8145-8150. http://dx.doi.org/10.1073/pnas.121177998

[21] Baulieua, E.E., Thomas, G., Legrain, S., Lahlou, N., Roger, M., Debuire, B., Faucounau, V., Girard, L., Hervy, M.P., Latour, F., Leaud, M.C., Mokrane, A., Pitti-Ferrandi, H., Trivalle, C., Lacharrière, O., Nouveau, S., Rakoto-Arison, B., Souberbielle, J.C., Raison, J., Le Bouc, Y., Raynaud, A., Girerd, X. and Forette, F. (2000) Dehydroepiandrosterone (DHEA), DHEA Sulfate, and Aging: Contribution of the DHEAge Study to a Sociobiomedical Issue. Proceedings of the National Academy of Sciences of the United States of America, 97, 4279-4284. http://dx.doi.org/10.1073/pnas.97.8.4279

[22] Labrie, F., Luu-The, V., Martel, C., Chernomoretz, A., Calvo, E., Morissette, J. and Labrie, C. (2006) Dehydroepiandrosterone (DHEA) Is an Anabolic Steroid like Dihydrotestosterone (DHT), the Most Potent Natural Androgen, and Tetrahydrogestrinone (THG). The Journal of Steroid Biochemistry and Molecular Biology, 100, 52-58. http://dx.doi.org/10.1016/j.jsbmb.2006.03.006

[23] Ramaraj, P. and Cox, J.L. (2014) In-Vitro Effect of Sex Steroids on Mouse Melanoma (B16F10) Cell Growth. CellBio, 3, 60-71. http://dx.doi.org/10.4236/cellbio.2014.32007

[24] Ramaraj, P. and Cox, J.L. (2014) In-Vitro Effect of Progesterone on Human Melanoma (BLM) Cell Growth. International Journal of Clinical and Experimental Medicine, 7, 3941-3953.

[25] Mosmann, T. (1983) Rapid Colorimetric Assay for Cellular Growth and Survival: Application to Proliferation and Cytotoxicity Assays. Journal of Immunological Methods, 65, 55-63. http://dx.doi.org/10.1016/0022-1759(83)90303-4

[26] Brown, C., Pan, X. and Hassid, A. (1999) Nitric Oxide and C-Type Atrial Natriuretic Peptide Stimulate Primary Aortic Smooth Muscle Cell Migration via a cGMP-Dependent Mechanism: Relationship to Microfilament Dissociation and Altered Cell Morphology. Circulation Research, 84, 655-667. http://dx.doi.org/10.1161/01.RES.84.6.655

[27] Ramaraj, P., Artaza, J.N., Sinha-Hikim, I. and Taylor, W.E. (2015) Effect of Androstenedione on Adipogenesis in Murine C3H10T1/2 Mesenchymal Cells. Open Journal of Endocrine and Metabolic Diseases, 5, 9-18. http://dx.doi.org/10.4236/ojemd.2015.52002

[28] Bennet, C.N., Ross, S.E., Longo, K.A., Bajnok, L., Hemati, N., Johnson, K.W., Harrison, S.D. and MacDougald, O.A. (2002) Regulation of Wnt Signaling during Adipogenesis. Journal of Biological Chemistry, 277, 30998-31004. 
http://dx.doi.org/10.1074/jbc.M204527200

[29] Kawai, S., Yahata, N., Nishida, S., Nagai, K. and Mizushima, Y. (1995) Dehydroepiandrosterone Inhibits B16 Mouse Melanoma Cell Growth by Induction of Differentiation. Anticancer Research, 15, 427-431.

[30] Dowling, S., Cox, J. and Cenedella, R.J. (2009) Inhibition of Fatty Acid Synthase by Orlistat Accelerates Gastric Tumor Cell Apoptosis in Culture and Increases Survival Rates in Gastric Tumor Bearing Mice in Vivo. Lipids, 44, 489498. http://dx.doi.org/10.1007/s11745-009-3298-2

[31] Williams, M.R., Ling, S., Dawood, T., Hashimura, K., Dai, A., Li, H., Liu, J.P., Funder, J.W., Sudhir, K. and Komesaroff, P.A. (2002) Dehydroepiandrosterone Inhibits Human Vascular Smooth Muscle Cell Proliferation Independent of ARs and ERs. The Journal of Clinical Endocrinology \& Metabolism, 87, 176-181. http://dx.doi.org/10.1210/jcem.87.1.8161

[32] Chen, J., Xu, L. and Huang, C. (2014) DHEA Inhibits Vascular Remodeling Following Arterial Injury: A Possible Role in Suppression of Inflammation and Oxidative Stress Derived from Vascular Smooth Muscle Cells. Molecular and Cellular Biochemistry, 388, 75-84. http://dx.doi.org/10.1007/s11010-013-1900-7

[33] McIntosh, M., Hausman, D., Martin, R. and Hausman, G. (1998) Dehydroepiandrosterone Attenuates Preadipocyte Growth in Primary Cultures of Stromal-Vascular Cells. American Journal of Physiology, 275, E285-E293.

[34] Shantz, L.M., Talalay, P. and Gordon, G.B. (1989) Mechanism of Inhibition of Growth of 3T3-L1 Fibroblasts and Their Differentiation to Adipocytes by Dehydroepiandrosterone and Related Steroids: Role of Glucose-6-Phosphate Dehydrogenase. Proceedings of the National Academy of Sciences of the United States of America, 86, 3252-3856. http://dx.doi.org/10.1073/pnas.86.10.3852

[35] Jasuja, R., Ramaraj, P., Mac, R.P., Singh, A.B., Storer, T.W., Artaza, J.N., Miller, A., Singh, R., Taylor, W.E., Lee, M.L., Davidson, T., Sinha-Hikim, I., Gonzalez-Cadavid, N. and Bhasin, S. (2005) 4-4-Androstene-3,17-Dione Binds Androgen Receptor, Promotes Myogenesis in Vitro, and Increases Serum Testosterone Levels, Fat-Free Mass, and Muscle Strength in Hypogonadal Men. The Journal of Clinical Endocrinology \& Metabolism, 90, 855-863. http://dx.doi.org/10.1210/jc.2004-1577

[36] Singh, R., Artaza, J.N., Taylor, W.E., Gonzalez-Cadavid, N.F. and Bhasin, S. (2003) Androgens Stimulate Myogenic Differentiation and Inhibit Adipogenesis in C3H10T1/2 Pluripotent Cells through an Androgen Receptor-Mediated Pathway. Endocrinology, 144, 5081-5088.

[37] Singh, R., Artaza, J.N., Taylor, W.E., Braga, M., Yum, X., Gonzalez-Cadavid, N. and Bhasin, S. (2006) Testosterone Inhibits Adipogenic Differentiation in 3T3-L1 Cells; Nuclear Translocation of Androgen Receptor Complex with BetaCatenin and T-Cell Factor 4 May Bypass Canonical Wnt Signaling to Down-Regulate Adipogenic Transcription Factors. Endocrinology, 147, 141-154. http://dx.doi.org/10.1210/en.2004-1649

[38] Bowers, L.D. (1999) Oral DHEA Supplementation Can Increase the Testosterone/Epitestosterone Ratio. Clinical Chemistry, 45, 295-297.

[39] Burke, L.M. (2000) Positive Drug Tests from Supplements. Sportscience, 4.

http://www.sportsci.org/jour/0003/lmb.html

[40] Nybo, K. (2015) A Whole New Ball Game. Biotechniques, 59.

http://www.biotechniques.com/news/A-Whole-New-Ball-Game/biotechniques-348117.html?\#.VdACTvm6eUl

\author{
Abbreviation \\ DHEA—dehydroepiandrosterone \\ DHEAS—dehydroepiandrosterone-sulfate \\ DHT-dihydrotestosterone \\ T-testosterone \\ IOC-International Olympic Committee
}

